\title{
地面効果特性の数値的および実験的研究
}

\section{Experimental and Numerical Study on Wing in Ground Effect}

\author{
○学 柘植 洋一（岐阜大院） 正 菊地 聡（岐阜大） \\ 正 小里 泰章（岐阜大）正 今尾 茂樹（岐阜大）
}

Yoichi TSUGE, Graduate School of Gifu University, 1-1, Yanagido, Gifu-shi, Gifu Satoshi KIKUCHI, Yasuaki KOZATO and Shigeki IMAO, Gifu University, 1-1, Yanagido, Gifu-shi, Gifu

Key Words: Wing in Ground Effect, Lift, Drag, Pressure Coefficient

\section{1. 緒 言}

翼が地面や水面等の境界面近傍を飛行する際, 揚抗比 が大幅に上昇する現象を地面効果と呼ぶ，近年この現象 を利用することで少エネルギー化が見込める輸送システ ムとしてエアロトレインが提案され開発が進められてい る(1). 地面効果には，翼が境界面に近づくことによる翼 下面の圧力変化が深く関っていることが知られており, 本研究では翼下面形状の異なる 3 つの翼モデルを用いて 風洞実験を行い, 空力特性や圧力特性を測ることで, 翼 形状の地面効果に対する影響を調查した。 また同時に直 接数值シミュレーションを行うことで, 実験では計測が 困難なデー夕を補完することにより, 翼下面形状と地面 効果の関係をより詳細に調べた。

\section{2. 実験装置および方法}

図 1 に実験装置図を示す。実験には半回流式風洞を用 い，測定部は開放型で使用した，翼前縁を原点とし，下 流方向を $x$, 主流と垂直な高さ方向を $y$ とする. 翼モデ ルは翼弦長 $c=152 \mathrm{~mm}$, 翼幅 $b=295 \mathrm{~mm}$ であり, 支持棒を 介し三分力天秤に固定することで, 揚力, 抗力, モ一メ ントを計測する. 主流速度は $20 \mathrm{~m} / \mathrm{s}$, 迎角 $\alpha=4^{\circ}$ で一定 とし, 翼後縁と地面板との距離 $h$ を変化させ揚力, 抗力 およびモーメントを測定した。地面の模擬には固定地面 板法を用いた。また, 地面板には静圧孔を複数設け, 地 面板上の圧力分布を測定した. 図 2 に本研究に用いた 3 種類の翼型を示す.エアロトレインの実走行モデルにも 使用されている NACA6412 改を基本とし, 翼上面形状は 全て同一とし，翼下面形状を凸型，凹型とした。 NACA6412 改翼型を Model1, 下面が凸型をModel2, 下 面が凹型を Mode13 と呼ぶ. 図 3 に直接数值シミュレー ションに用いた計算領域およびグリッドを示す。数值計 算には CFD2000(Adaptive Research 社)を使用した。これ は連続の式と Navier-Stokes 方程式を有限体積法で解くコ 一ドである。計算は全面乱流で行い, 乱流モデルには標 準 $\mathrm{k}-\varepsilon$ モデルを使用している. 計算領域は長方形で大 きさは翼弦長を 1 として, $x$ 方向は翼前縁から上流に 2 , 翼後縁から下流に $2, y$ 方向は翼後緑から上方へ 2 とし た。計算格子は L 型格子を用いて, 流れの変化が激しい 翼近傍で細かくなるよう設定した。計算領域の大きさ, グリッドの細かさは領域, グリッドを変化させて適性で あることを確認している.レイノルズ数は風洞実験と同 じ $R e=2 \times 10^{5}$ とした.

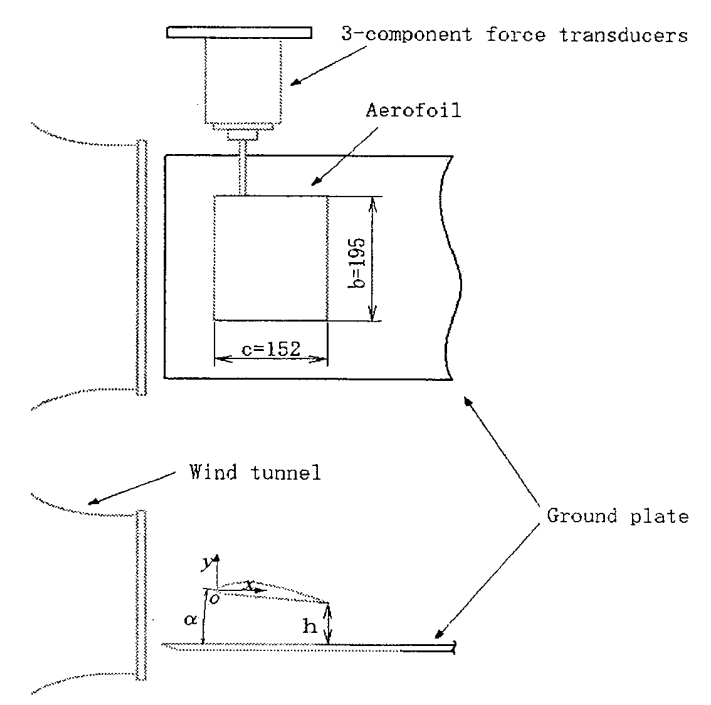

Fig.1 Experimental setup

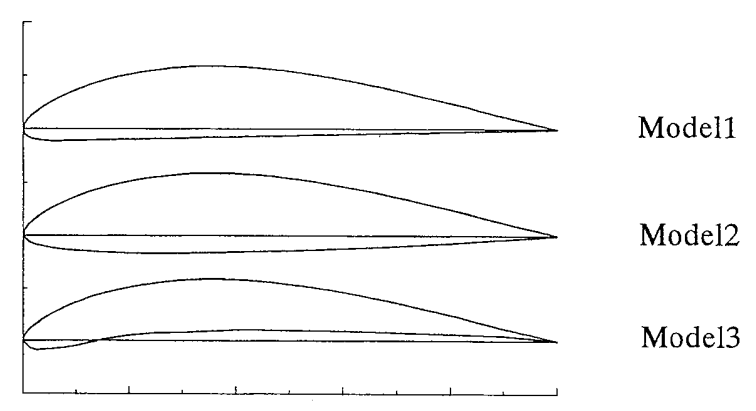

Fig. 2 Profile

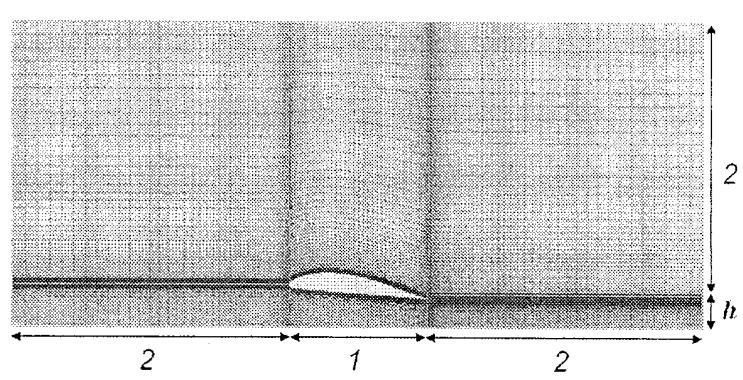

Fig.3 Computational area and grid 


\section{3. 実験結果と考察}

図 4 に風洞実験による各翼型の $C_{L}$ と $C_{D}$ の変化を示す. どの翼型も $h / c$ が小さくなるにつれて $C_{L}$ は上昇し, $h / c$ の減少率に対する $C_{L}$ の增加率も高くなっており, 過去の 研究結果と一致する(2). 翼型による $C_{L}$ の違いを見ると， Model3 が全ての $h / c$ について最も大きく，これは翼下面 之地面板の間の流路がチャンバー形状になる為に流速が 遅い，つまり圧力が高い領域が大きいためと考元られる。 次に $C_{D}$ を見ると, どの翼型も $h / c$ が小さくなるにつれて 減少しており, $h / c$ が 0.1 以下で急激に減少している. Model3 が他の翼型に比べ, 大きくなった. 図 5 に直接数 值シミュレーションにより求めた各翼型の $C_{L}$ と $C_{D}$ の変 化を示す、実験とシミュレーションには、翼幅が有限と 無限（2 次元）の違いと、地面が固定と移動の違いがあ る。計算による $C_{L}$ の変化は定性的に風洞実験結果と同じ 傾向を示したが, 翼幅無限のため大きな $C_{L}$ となった. $C_{D}$ は $h / c \geqq 0.1$ の領域で $h / c$ が小さくなるに従って緩やか に減少するが, $h / c<0.1$ では $h / c$ が小さくなるにつれ $C_{D}$ が增加する結果となり，風洞実験と逆の傾向を示した。 これは風洞実験において, 翼モデルが地面板上の境界首 による低流速域に入ったために $C_{D}$ が減少したためと考 えられる. また図 4 の風洞実験では最も $C_{D}$ の高かった Model3 が, 数值シミュレーションでは他の翼型と同程度 になるといら変化がみられた。

図 6,7 に風洞実験による翼下方の地面板上の圧力係 数 $C_{P}$ の分布を示す. 図 6 は Model1 の, 図 7 は Model3 の結果を示している. 翼下面と地面板の間の流路形状と 圧力の分布を比較するためにグラフの上には，それぞれ の翼型を表示している. どちらの翼型も $h / c$ が小さくな るにつれて， $C_{P}$ は高くなっている.この $C_{P}$ の上昇が地 面効果による揚力増加の大きな原因である. Model3 㟊翼 下面の形状と同じく上に凸の分布となるが, Model1 は前 縁から後縁に向けて単調減少の分布となる。ここで翼下 面形状と $C_{P}$ 分布の関係を詳しく見る. Model3 で $x / c=0.25$ 〜0.6での翼下面と地面がなす流路は狭くなるので, 下 面と地面の間を流れる流量を一定とするならば，流れは 加速され $C_{P}$ 汹減少するはずだが, 図 6 を見るとこの領域 で $C_{P}$ は增加している.これは凹部での翼端からの流出が 多く, 流量の減少に伴い流れが減速して $C_{P}$ が高くなって いると思われる. Model1 の $C_{P}$ 分布をみると，この様な 現象はみられず，この凹部での翼端からの流出が大きい ことが, $C_{D}$ の增加を引き起こしていると考えられる。こ のことから, 翼下面が凹型の翼型は, 低アスペクト比の 翼では, 翼端からの流出が大きく, 抵抗が大きくなるが, 2 次元性を高めれば, 流出の問題が解決され高性能な翼 になることがわかる。

\section{参考文献}

（1）小濱他 1 名：地面効果とその応用, 日本機械学会流 体工学部門講演会公演論文集, $\operatorname{CDROM}(2001)$.

（2）都丸他 1 名：翼型の地面効果特性に関する実験的研 究,ながれ，Vol.10，(1991)，47.

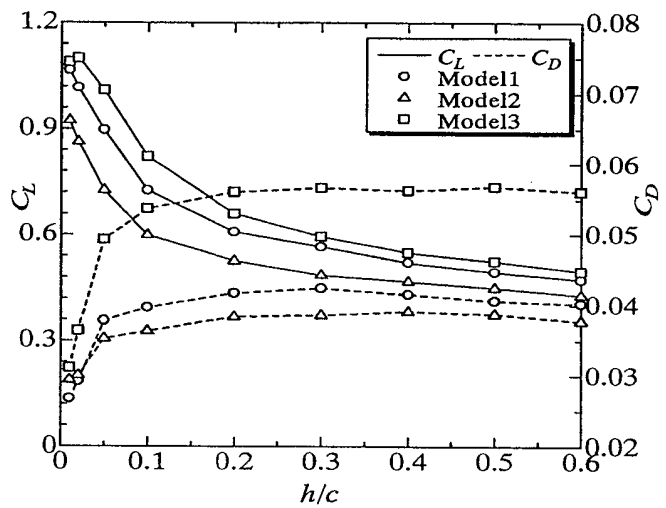

Fig.4 Lift and drag coefficients (experiment)

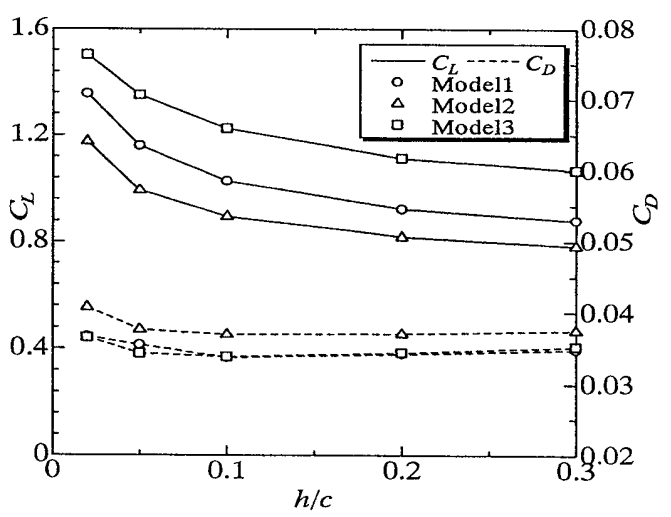

Fig.5 Lift and drag coefficients (simulation)

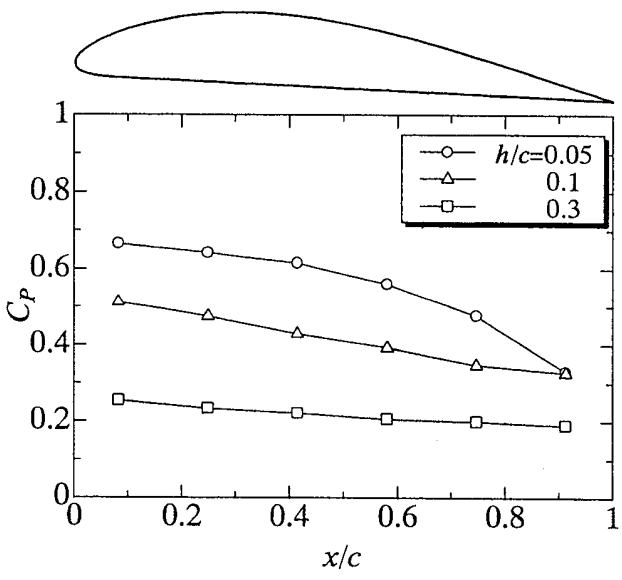

Fig.6 Pressure distribution (Model1)

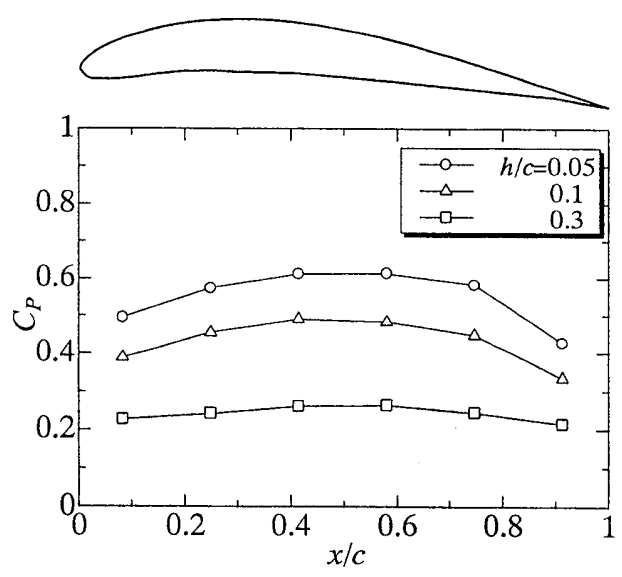

Fig.7 Pressure distribution (Model3) 